\title{
РАЗВИТИЕ ТЕОРИИ ХИКСА-ХАНСЕНА ДЛЯ НАЦИОНАЛЬНОЙ ЭКОНОМИКИ НА ПРИМЕРЕ РОССИЙСКОГО СЕГМЕНТА ГЛОБАЛЬНЫХ ФИНАНСОВ
}

\author{
(c) 2018 Шавшуков Вячеслав Михайлович \\ доктор экономических наук, профессор \\ Санкт-Петербургский государственный университет \\ 199034, г. Санкт-Петербург, Университетская наб., д. 7/9 \\ E-mail:v.shavhukov@spbu.ru; shavshukov@rambler.ru
}

\section{(C) 2018 Гулый Илья Михайлович}

кандидат экономических наук, доцент

Петербургский государственный университет путей сообщения Императора Александра I

190031, Санкт-Петербург, Московский проспект, д. 9

E-mail: ilya.guliy@mail.ru

В статье развивается теория функционирования национальной экономики на основе модели Хикса-Хансена IS-LM. Предложена модель четырех рынков. В нее включен национальный сегмент глобальных финансов, который стал частью международных рынков реальных и финансовых активов. Объектом анализа стали денежные потоки от экспортной выручки, заимствований, эмиссий, инвестиционных процентных и непроцентных доходов. Проходя через валютообменные операции, они соединяются с внутренними потоками предложения денег. Обратный поток денег, финансовых трансферов, регистрируемый в платежном балансе, сальдируется и корректируется валютным курсом. Предметом анализа стали входящие в страну и исходящие потоки, корректирующие их величину валютные курсы, эффекты внешнего фактора на предложения денег и объем инвестиций. Рассмотрено влияние цены денег, платежного баланса, темпов роста экономики, параметров денежно-кредитной политики на валютный курс. Разработана математическая модель прогнозирования валютного курса, включающая внешнеэкономические факторы движения товаров, денег и капитала.

Ключевые слова: модификация модели Хикса-Хансена IS-LM, модель четырех рынков, национальные финансы, глобальные финансы, курс национальной валюты, денежный рынок, рынок капитала, математическое моделирование валютных курсов.

В 80-е гг. XX века сформировалась глобальная финансово-экономическая система, в которой национальные экономики являются ее составной частью, сегментом. Одним из признаков системы является свободное движение капитала, товаров, технологий, информации, людей, которое придает импульс мировой экономике. Модернизация многих национальных экономик стала результатом привлечения прямых иностранных инвестиций, фондирования с международных финансовых рынков, создания ориентированных на экспорт отраслей. В национальные экономики входят финансовые потоки от экспортной выручки, заимствований государств и бизнеса, эмиссии долговых обязательств, размещенных на международных рынках. Выходят трансферы в оплату за импорт товаров и услуг, кредиты, инвестиции в реальные и финансовые активы, платежи по процентным и непроцентным доходам.

Платежный баланс стран адекватно отражает движение этих потоков (см. табл. 1).

Для большинства экономик текущий счет платежного баланса положителен. В частности, в 2017 г. в ведущую группу стран по данному показателю вошли Германия (\$327 млрд.), Япония (184), КНР (98), Россия (97), Южная Корея $(82,2)$, Саудовская Аравия $(65,5)$, Италия $(41)$, Норвегия (\$34,4 млрд.). Отрицательное сальдо имели США (\$515,8 млрд.) Великобритания $(99,2)$, развивающиеся страны Европы (53,2), G7 (140,9), Франция (26), Турция (41), Африка (кроме Нигерии и Ливии), Австралия (40), Бразилия (\$25 млрд) [13].

Страны с положительным сальдо платежного баланса приращивали объем национальных финансов за счет международных рынков. Экономики с отрицательным платежным балансом финансировали третьи страны. При этом, почти 
Таблица. 1. Текущий счет платежного баланса, 2018, млрд. долл. США

\begin{tabular}{|l|c|}
\hline \multicolumn{1}{|c|}{ Аналитическая группа } & Объем \\
\hline Развитые экономики & 380,383 \\
\hline Страны СНГ & 86,359 \\
\hline Развивающиеся страны Азии & 28,228 \\
\hline Развивающиеся страны Европы & $-53,206$ \\
\hline ЕС & 429,03 \\
\hline Страны Латинской Америки и Карибского бассейна & $-85,588$ \\
\hline Страны G7 & $-140,856$ \\
\hline Средний Восток и Северная Африка & 80,063 \\
\hline Средний Восток и Северная Африка, Афганистан и Пакистан & 62,94 \\
\hline Другие развитые экономики & 370,431 \\
\hline Страны субсахарской Африки & $-46,144$ \\
\hline Мир & 372.972 \\
\hline
\end{tabular}

Источник. Составлено по [13].

все входящие и исходящие денежные потоки проходят через валюта-обменные операции. Их размер определяется валютным курсом [3].

Большинство стран положительное сальдо платежного баланса обеспечили с помощью активного торгового баланса, полученного за счет значимой доли (не менее 3-13\%) на мировых рынках факторов производства и товаров. В частности, в России за период 2006-2017 гг. доля экспорта к ВВП страны составляла в среднем 28\% с диапазоном от 25,79\% (2016) до 33,73\% (2006) [10]. В стоимостном выражении в 2017 г. объем экспорта был на уровне \$584,050 млрд. (импорт \$226,966 млрд.) с положительным сальдо торгового баланса в размере \$130,117 млрд. [10].

Качество жизни, конкурентоспособность и размер национальных экономик в значительной степени обусловлены участием страны в финансовых потоках на международных рынках. Сальдо финансового счета платежного баланса отражает эти зависимости. Масштабы и качество интегрированности в глобальные финансы проявляются в размерах и интенсивности финансовых потоков, в конечном итоге, влияют на ВВП на душу населения (Рисунок 1. «Соотношение удельного значения сальдо финансового счета платежного баланса (\%) и душевого ВВП по странам мира»).

Функционирование национальной экономики, как органическое взаимодействие трех рынков (денег, рабочей силы, товаров) было представлено в кейнсианской модели Хикса-Хансена IS-LM. Формирование глобальной финансовоэкономической среды не было учтено. Национальные экономики стали ее частью, как экс- портеры/импортеры товаров и услуг, кредиторы, инвесторы/реципиенты внешнего финансирования. Экономики стран финансируется не только за счет внутреннего рынка, но и внешнего. Эти потоки денег отражаются в платежном балансе, сальдируются с оттоками.

Насколько платежный баланс адекватно отражает эти потоки? В мировой экономике существует «невидимая», «теневая» экономика. Ее годовой оборот не известен, но экспертно оценивается в \$0,7-1,2 трлн. Структурно он состоит из доходов от нелегальной продажи оружия и рабочей силы, наркобизнеса и трафика, порнобизнеса, теневой экономики, ОПГ, контрабанды (в оборотах невидимой экономики не учитывается уклонение от налогов). Вышеназванные денежные потоки идут под другим именем в грузовой таможенной декларации (тарифном наименовании товара, отгрузочной спецификации) и под другими реквизитами в платежном поручении по стандартам SWIFT: поля 50 (плательщик), 59 (получатель), 70 (назначение платежа), 72 (дополнительная информация для получателя и банка получателя). Эти денежные потоки рано или поздно проходят конвертацию на валютном рынке и «отмываются» в банках, не делают платежные балансы стран, форекс и кредитные институты абсолютно чистыми, прозрачными, свободными от тени невидимой экономики.

Для глобальной экономики свободное движение денег, капитала является сущностным признаком и чертой. Размер встречных потоков от экспорта/импорта, притока/оттока капитала определяется курсом национальной валюты 


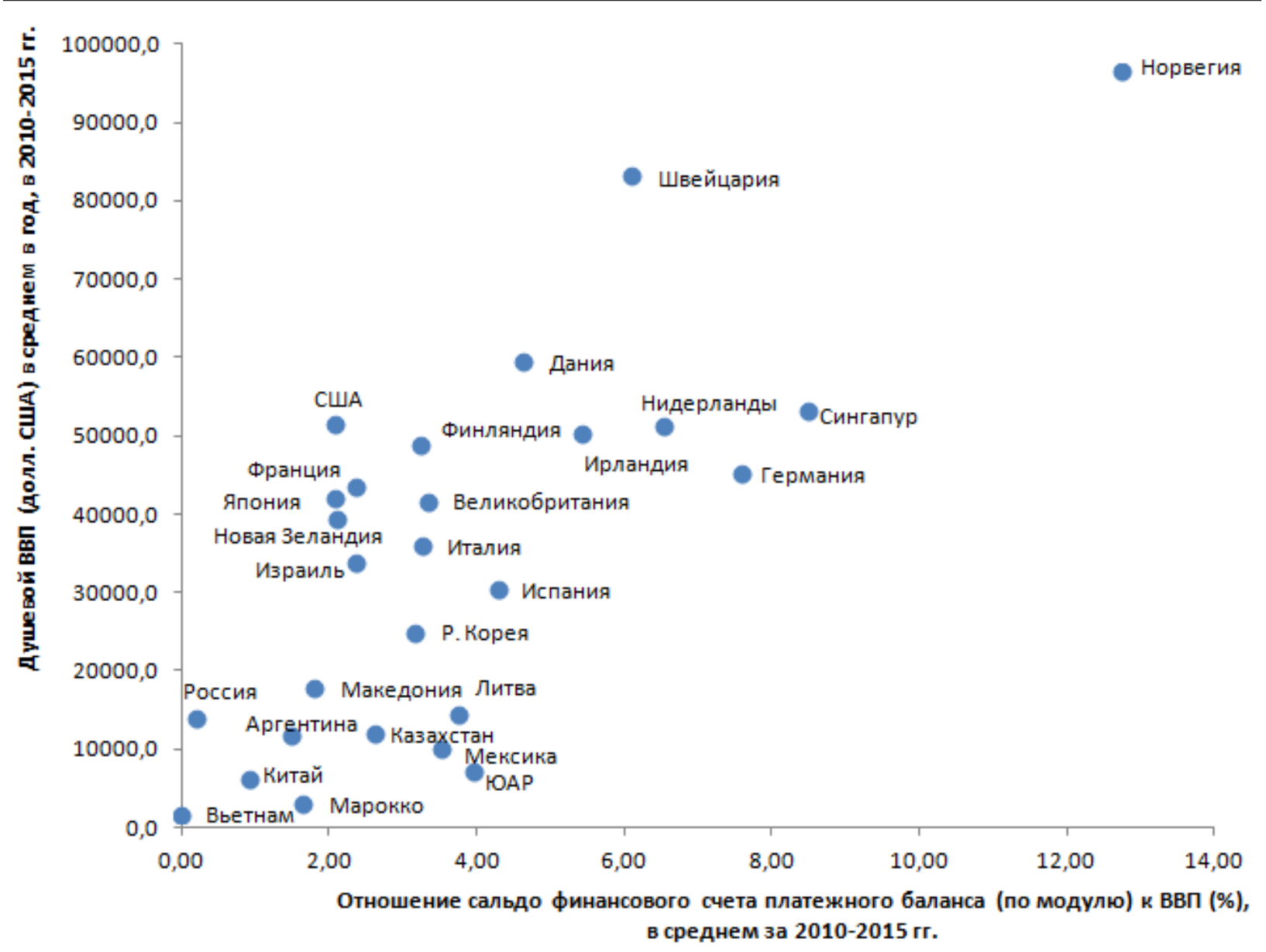

Рuc. 1. Соотношение удельного значения сальдо финансового счета платежного баланса (\%) и душевого ВВП по странам мира Источник. Рассчитано и построено на основе [24].

к основным валютам международных расчетов. Монетарные власти приветствуют не только положительное торговое сальдо, превышение притока капитала над оттоком, но и привлекательный для национальных экспортеров валютный курс.

Основная научная гипотеза заключается в том, чтобы интегрировать в модель Хикса-Хансена международный рынок финансовых активов: форекс и стоящие за ним рынки денег, долговых обязательств и капитала. Предлагается модифицировать модель трех рынков Хикса-Хансена, сделав ее моделью четырех рынков. В национальную экономику входят два потока денег с внутреннего рынка и внешнего. Их следует не только считать, анализировать, но и прогнозировать. Направлением анализа должны быть масса денег по денежным агрегатам, оценка «лишних денег» и их стерилизация, платежный баланс, государственный и корпоративный внешний долг, уровень инфляции, эффективный валютный курс и валютная политика ЦБ.

\section{Основная часть}

1. Методологические основы включения внешних финансовых рынков в модель Хикса-Хансена IS-LM. В качестве методологического подхода используется модифицированная «модель трех рынков»: денег, товаров и труда. Предлагаемая принципиальная схема функционирования четырех рынков (рисунок 2) иллюстрирует потоки денег в мировой и национальных экономиках. В модель включен валютный рынок с двумя сегментами: национальный и международный. В условиях глобальной экономики импульс на национальные рынки товаров и труда приходит не только с внутреннего денежного рынка, но и международного. Цена финансирования с использованием различных инструментов становится регулятором движения денег и капитала в глобальной финансовой среде. Существенную роль в межстрановых потоках играет фактор курса валюты, ее волатильность и стабильность. Текущий счет платежного баланса становится воротами двухсторонних потоков валюты и тон- 


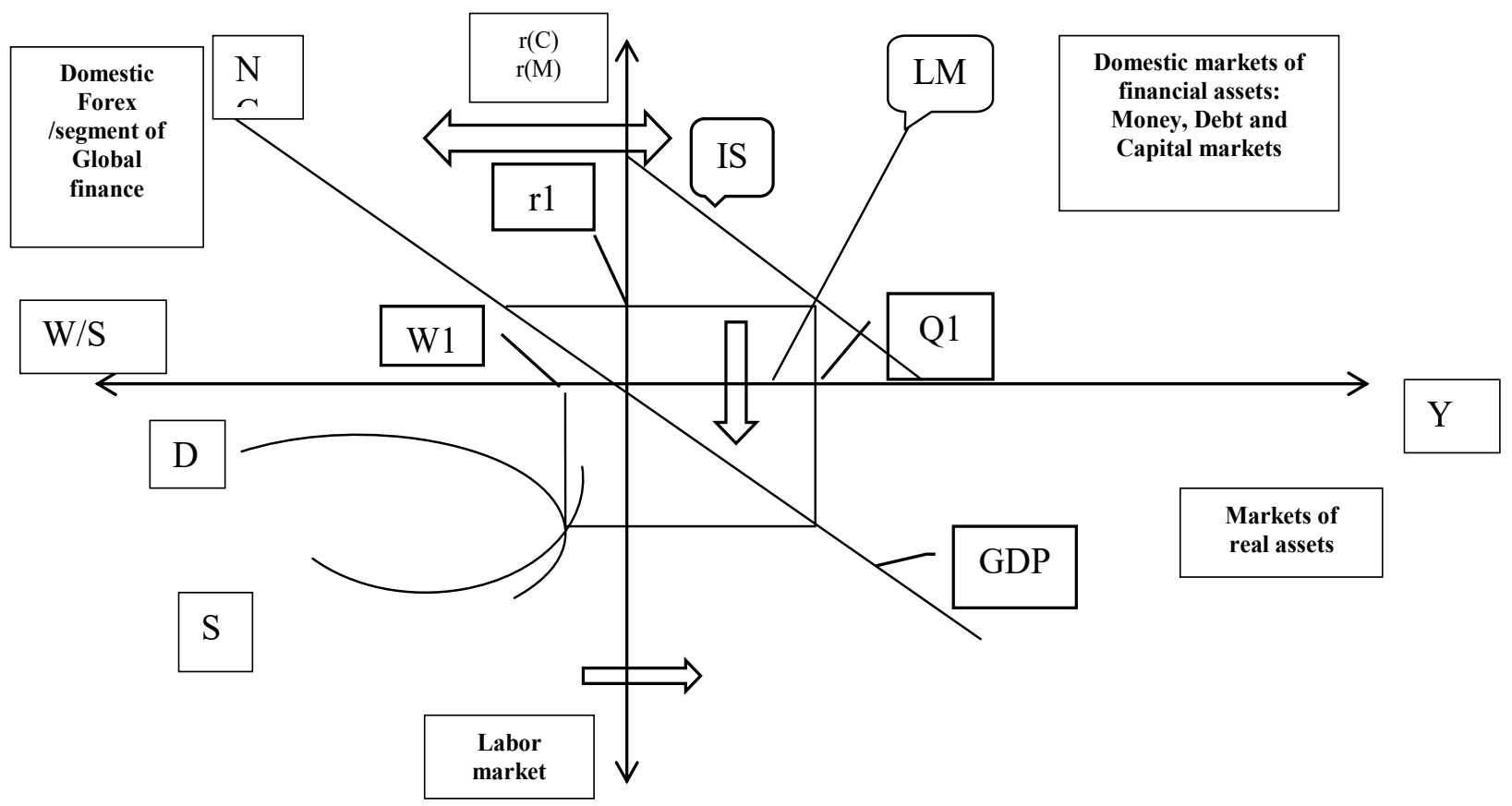

Puc. 2. Модель четырех рынков национальной экономики Источник. Составлено авторами.

ким индикатором ее здоровья.

На профицит / дефицит платежного баланса влияет много факторов. Среди них разница внутренних и мировых цен на рынках реальных и финансовых активов, а также валютный курс. Он является фактором преференции в стратегии экспортно-ориентированных экономик, а также важным источником пополнения государственных и корпоративных бюджетов.

2. Форекс, предложение и цуена денег в национальной финансовой системе.

Схема четырех рынков иллюстрирует приток / отток валюты, их влияние на предложение и цену денег, инвестиционные возможности и финансирование экономики, производство валового внутреннего продукта (далее ВВП) и занятость, в конечном итоге экономический рост и качество жизни. Рассмотрим (с точки зрения детерминизма) пять случаев влияния цены денег и валютного курса на платежный баланс, денежно-кредитную и валютную политику центрального банка (далее - ЦБ).

Случай $A$. Если на национальном рынке денег при rl QS > QD, то возникает понижательный тренд их цены. Курс иностранной валюты падает, а ЦБ для удержания стабильности курса производит интервенции в национальной валюте. И, наоборот, при повышательном тренде цены денег, курс иностранной валюты растет, ЦБ осуществляет интервенции в инвалюте за счет валютных резервов. Изменение регулятором ключевой ставки в данном случае зависит от конъюнктуры товарных рынков и экономического цикла.

Рисунок 3 демонстрирует заметное влияние среднерыночной цены капитала на валютный курс РФ в период с 2010 по 2016 гг. Очень непростой период для денежно-кредитной политики следует охарактеризовать как результативный, поскольку динамика ключевой ставки положительно оказывала влияние на валютный курс рубля.

Случай В. При положительном сальдо текущего счета платежного баланса, приток иностранной валюты больше его оттока, то валютный курс имеет понижательный тренд. И наоборот. Существенное влияние сальдо счета текущих операций на валютный курс рубля прослеживалось на протяжении периода экономического подъема 2000-2008 гг. В основном укрепление рубля в этот период было связано с сокращением отрицательного сальдо доходов от инвестиций и существенным ежегодным приростом положительного сальдо торгового баланса (рисунок 4). Таким образом, рост положительного сальдо текущего счета платежного баланса является фактором укрепления валютного курса национальной валюты.

Случай С. При возникновении положительного сальдо торгового баланса приток иностран- 


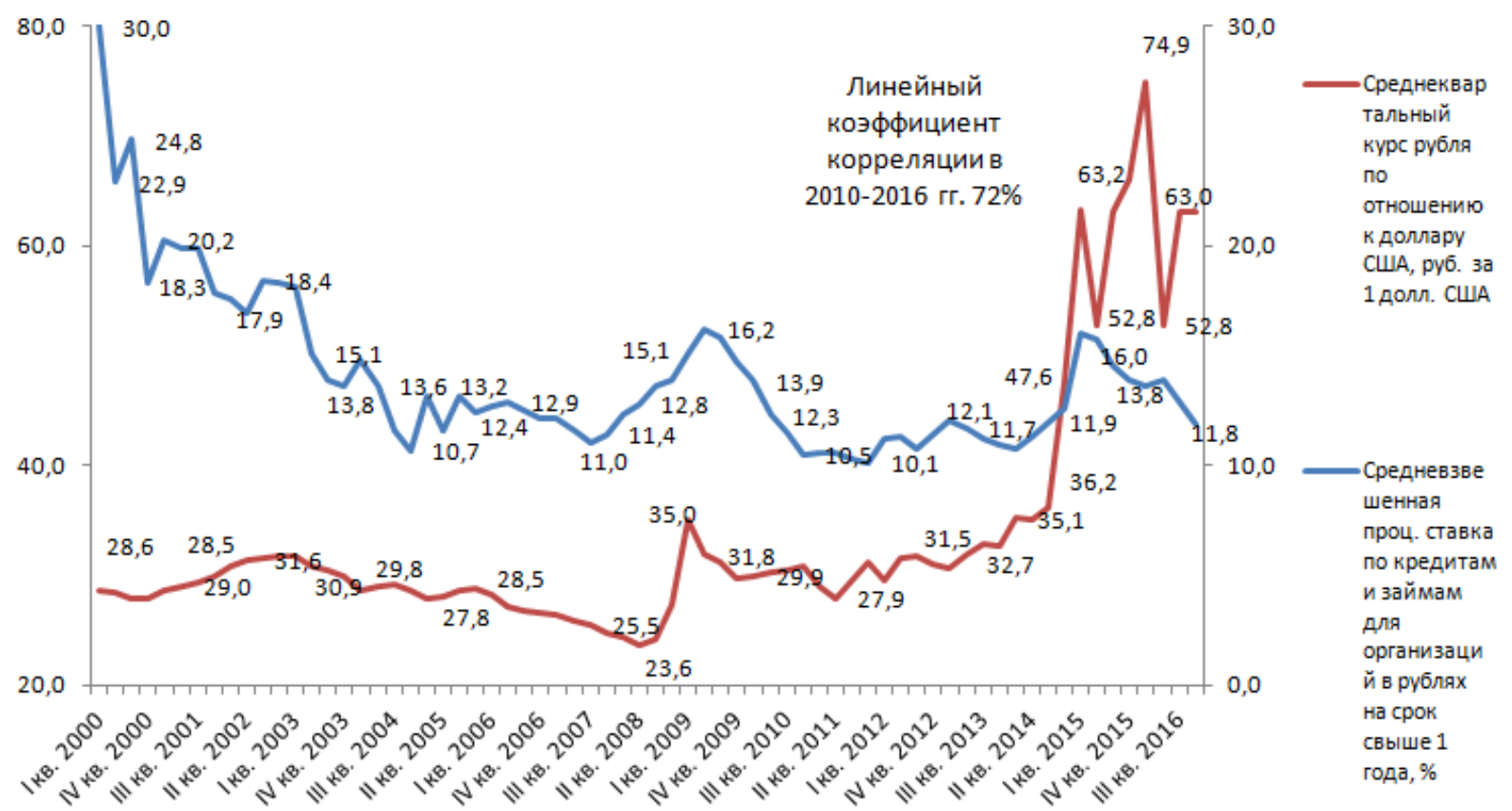

Puc. 3. Динамические ряды - тренды цены капитала (оцениваемой по средневзвешенной ставке по кредитам и займам в рублях для юридических лиц) (\%) и валютного курса национальной валюты PФ (1 USD / RUB).

Источник. Составлено по [2]

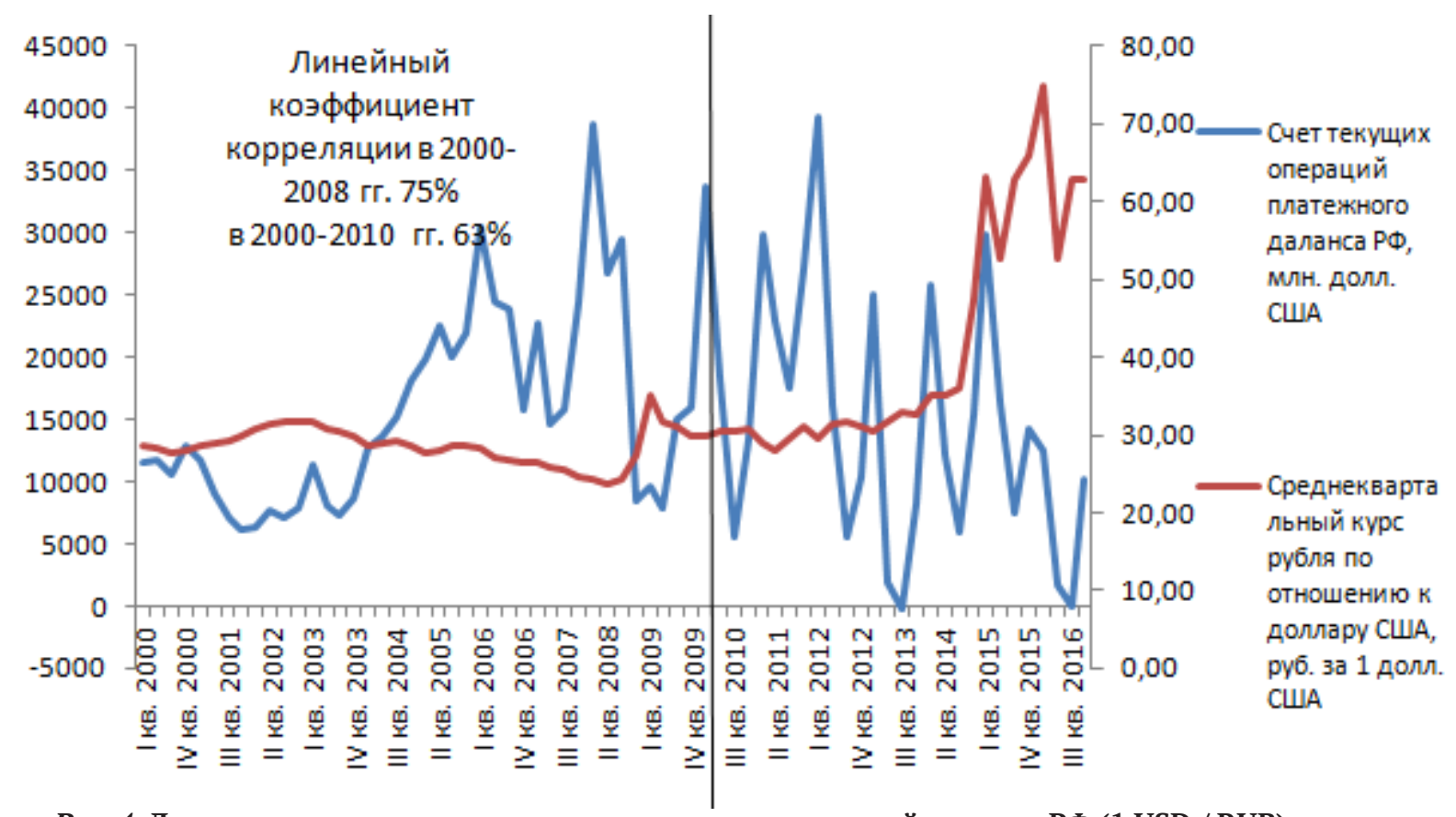

Puc. 4. Динамические ряды валютного курса национальной валюты РФ (1 USD / RUB) и счета текущих операций платежного баланса РФ (млн. долл. США) в 2000-2016 гт. 
ной валюты превышает его отток, то формируется понижательная тенденция валютного курса национальной валюты. Влияние положительного сальдо торгового баланса проявлялось в РФ на протяжении всего периода настоящего исследования, за исключением ситуации рецессии 2009 г. (рисунок 5). Нами выявлены, статистически подкрепленные, следующие зависимости. Увеличение положительного сальдо торгового баланса в 2007-2008 гг. до \$40-54 млрд. стимулировало укрепление национальной валюты до рекордного за последние 20 лет уровня курса рубля за \$1 23,6-24 руб. в 1 полугодии 2008 г. (здесь и далее применяется прямая котировка (1 USD/ RUB). При этом при сальдо торгового баланса в диапазоне от $\$ 30$ до $\$ 54$ млрд. курс рубля укрепляется в пределах 23-29 рублей. При более низких параметрах сальдо торгового баланса от $\$ 25$ до $\$ 30$ млрд. курс рубля снижался до 30-45 рублей, при дальнейшем сокращении сальдо торгового баланса курс рубля падал до 46-74 рублей.

Случай $D$. Если валюта является евровалютой, резервной, ценовым ориентиром, то на рынках реальных и финансовых активов и в политике ЦБ мира прослеживается ряд закономерностей.

1. Данная валюта включается центральными банками в свою международную ликвидность, становится сбережением для домашних хозяйств.
2. Валюта превращается в валюту заимствований и кредитования на международных рынках денет.

3. Валюта становится валютой эмиссии на рынках долговых обязательств и капитала.

4. Валюта становится валютой расчетов и платежей на международных рынках реальных и финансовых активов.

5. На рынке Forex валюта становится валютой конверсионных операций для экспортно-импортных сделок и валютой спекуляций.

Случай E. В случае дефолта монетарных властей происходит провал валютного рынка и девальвация валюты. В случае разбалансированности секторов национальной экономики и внутреннего рынка, начала кризиса / рецессии уходит национальный капитал и иностранные инвесторы. Эта подтверждается статистическими данными с 2011 г. Рост отрицательного сальдо капитальных активов сначала привел к ослаблению курса рубля, затем к его резкому падению в 2 раза по сравнению с предыдущим десятилетием (рис. 6). Таким образом, сальдо капитальных трансфертов платежного баланса в последние годы является влияющим фактором курса национальной валюты в РФ.

Продаются активы, деноминированные в национальной валюте. Нагрузка на Forex возрастает, спрос на иностранную валюту превы-

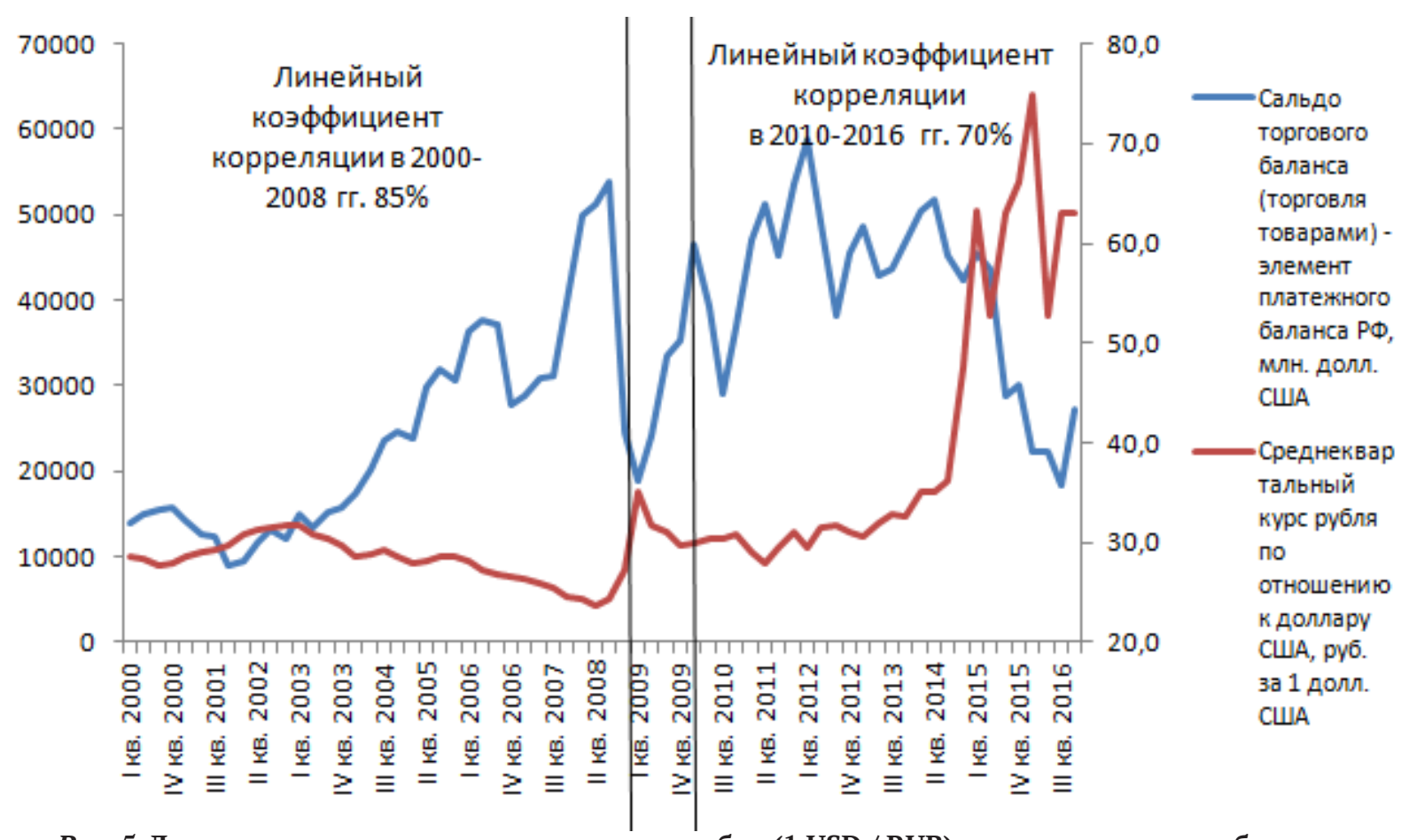

Puc. 5. Динамические ряды валютного курса рубля (1 USD / RUB) и сальдо торгового баланса (торговля товарами без торговли услугами), млн. долл. США в 2000-2016 гг. Источник. Составлено по [4]. 


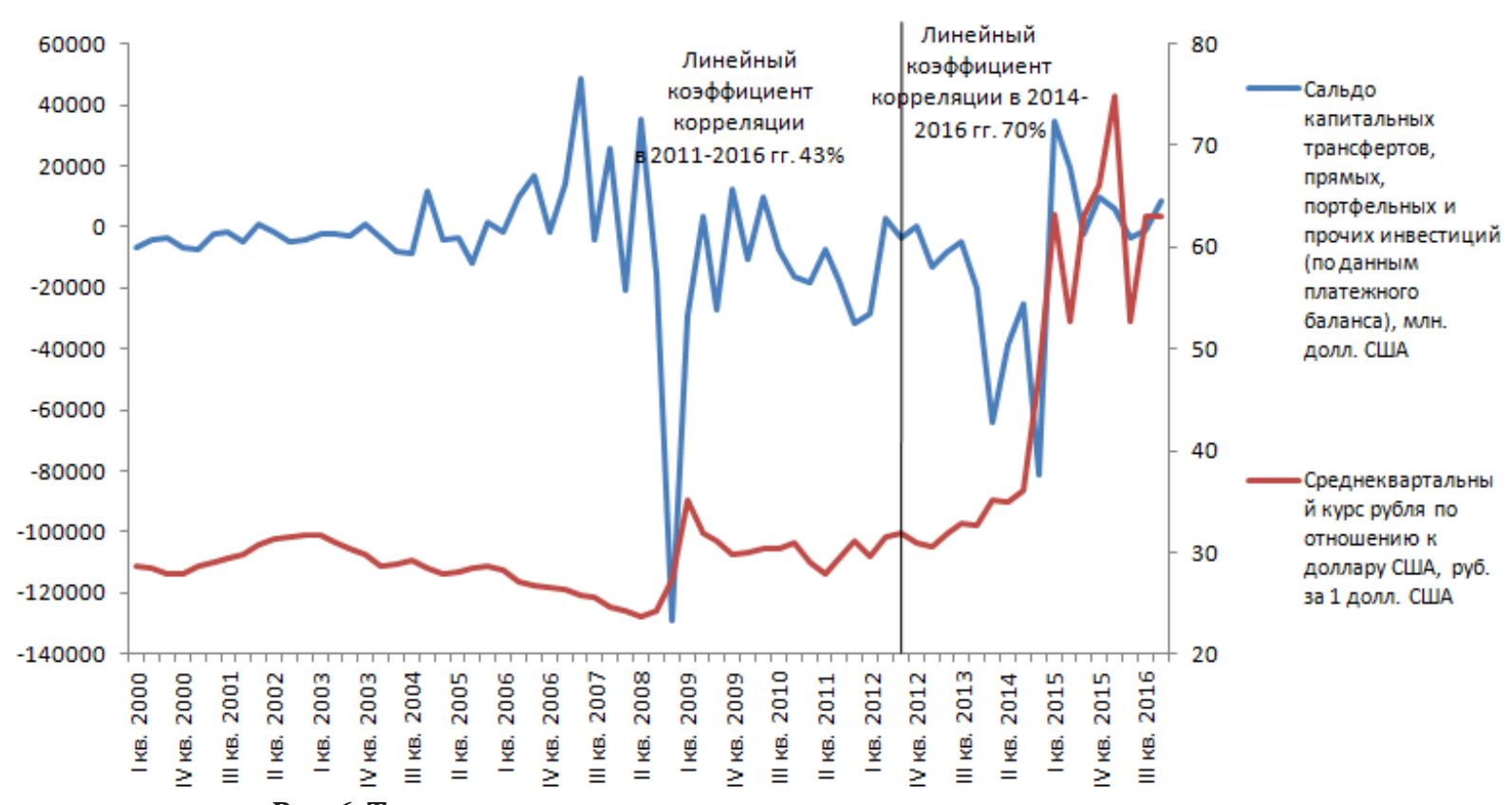

Puc. 6. Тренды динамики - сальдо капитальных активов и курса национальной валюты РФ в 2000-2016 гг.

Источник. Составлено по [24]

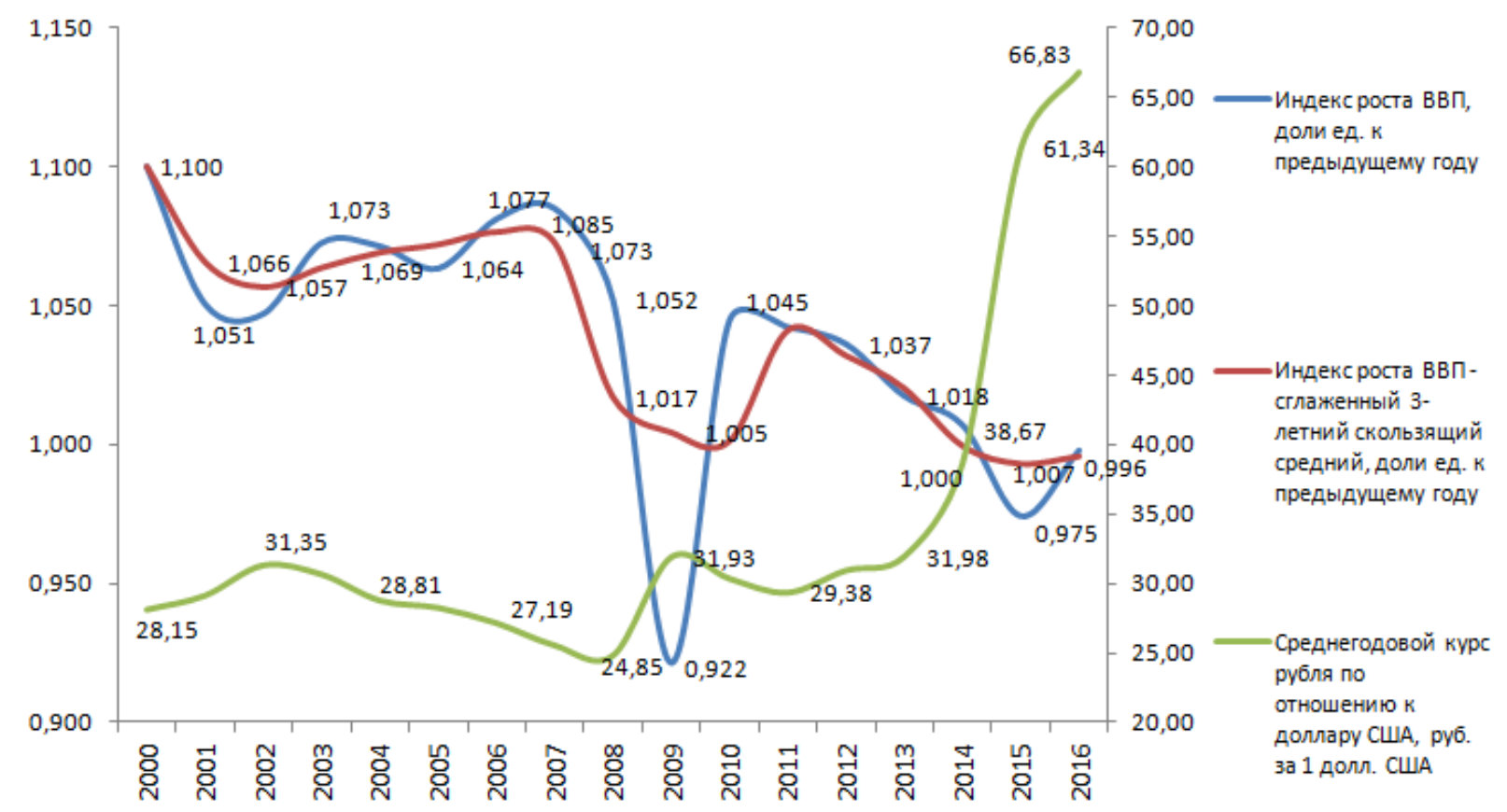

Puc. 7. Влияние фазы экономического развития (рост / спад) на валютный курс национальной валюты в 2000-2016 гг. Источник. Составлено по [23] 
шает предложение. ЦБ пытается удержать стабильность курса за счет своих золотовалютных резервов. Обычно это не удается и возникает причина для дефолта и девальвации валюты. В отношении РФ зависимость фазы экономического развития страны и величины валютного курса наглядно продемонстрировано на рисунке 7: экономический спад 2014-2016 гг. обусловил снижение курса национальной валюты до 60-67 руб.

Таким образом, положительная динамика экономического роста является фактором, стабилизирующим валютный курс национальной валюты.

\section{3. Дискуссия}

Данный раздел является логическим продолжением анализа методологических основ и результатов нашего исследования. Он исторически и теоретически является основой данной статьи. В ходе и после Великой депрессии (1929-1933 гг.) стало очевидно, что рынок не может обеспечить бескризисность развития национальной экономики. Возникла научная и практическая необходимость в разработке макроэкономической модели AD-AS (Aggregate Demand - Aggregate Supply model), рассматривающей макроэкономическое равновесие в условиях изменяющихся цен в краткосрочном и долгосрочном периодах. Впервые она была выдвинута в 1936 г. Дж. Мейнардом Кейнсом (John Maynard Keynes. "The General Theory of Employment, Interest and Money") [21] и стала основой для макроэкономического анализа для всех последующих экономистов и школ, включая Джоан Робинсон (Joan Robinson), Милтона Фридмана (Milton Freedman), многочисленных направлений пост-кейнсианства (Post-Keynesian Economics). Модель описала влияние AD и AS на цены, совокупный выпуск (GDP), фазы экономического цикла. Все 24 главы книги заложили не только макроэкономический фундамент Economics. На основе антикризисной политики «Нового курса» Рузвельта (Franklin Delano Roosevelt) в рамках программ NIRA, AAA, Дж. Кейнс создал теоретические основы государства как экономического агента и его кейнсианской экономической политики.

Дж. Кейнс подтолкнул научную мысль к дальнейшему развитию и конкретизации модели AD-AS. Уже в 1937 г. после ярких академических дискуссий в Оксфорде и Кембридже вышла книга Дж. Хикса (John Hicks «Mr. Keynes and the classics: A suggested interpretation» [19]) с обо- снованием модели IS-LM. В 1949 г. модель получила развитие в книге Э. Хансена (Alvin Hansen «Monetary theory and fiscal policy» [17]). Хансен стал «американским Кейнсом». Так началась история кейнсианства - великой экономической школы и экономической политики 20-го века.

Новация модели Хикса-Хансена (HicksHansen model IS-LM) состояла в том, что она описала общее макроэкономическое равновесие по Кейнсу путём комбинации моделей равновесия на товарном [кривая IS (инвестиции - сбережения)] и денежном [кривая LM (предпочтение ликвидности = спрос на деньги (L), деньги (M)] рынках. Каждая точка на кривой IS соответствует равновесию на товарном рынке, которое определяется соотношением ВВП (Y) и процентной ставки (i). Кривая IS моделирует зависимость объема инвестиций от процентной ставки. В свою очередь, каждая точка на кривой LM соответствует равновесию на денежном рынке. Кривая LM моделирует зависимость процентной ставки от национального дохода.

Модель Хикса-Хансена (Hicks-Hansen Model of IS-LM), фактически теория Хикса-Хансена, позволила системно, детерминировано, логично показать взаимосвязь процентной ставки, денежной массы, уровня цен, спроса на деньги, спроса на товары. Модель функционирования трех рынков в национальной экономике стала одной из выдающихся моделей макроэкономики.

Однако последующие работы Хикса (Nobel Prize Winner, Sir Hicks about (consumer`s surpluses, theory of monopoly, welfare economics, capital and growth, etc.) и Хансена (Hansen «Economic Policy and Full Employment, 1947; («Business Cycles and National Income», 1951; «The Dollar and the International Monetary System», 1965) не затронули и не могли затронуть формирования и функционирования глобальной финансово-экономической среды, т.е. 1 квадрант нашей концепции.

Обратимся к последним направлениям научных исследований в BIS и IMF. BIS, как главный методолог центральных банков мира в 2017-2018 гг. был сфокусирован на чрезвычайно важных исследованиях: рынки и инфраструктура деривативов; идентификация шоков цены на нефть; международный канал кредита и стандарты кредитования; таргетирование инфляции и макроэкономическая стабильность; эффекты финансовых регулирований на иностран- 
ные активы; глобальная разбалансированность с точки зрения перспектив фондового рынка; асимметрия между кредиторами и должниками; кредитный риск фирм и оффшорное звено в глобальном финансовом цикле [27]; цены, реальные и финансовые эффекты обменных курсов; роль процентных ставок в денежно-кредитной политике Китая [26]; финансовый и ценовая стабильность на развивающихся рынках: роль процентной ставки [22]; международный канал кредитования и обзоры стандартов кредитования [14].

Перечисленные темы исследований чрезвычайно актуальны, хорошо освещены, но не рассматривают национальные финансы сквозь призму глобальных.

К подобному выводу мы придем и после краткого анализа тематики исследований IMF в журнале Finance \& Development, 2016-2018. Назовем некоторые темы: Balancing Act: Managing the Public Purse: рост налогов vs снижение расходов (F\&D, March 2018); низкий экономический рост развитых экономик (F\&D, March 2017); глобальные инсайдеры и аутсайдеры (F\&D, March 2016); Африка: подъемы и спады (F\&D, March 2016); проблемы бедности (F\&D, June 2015).

4. Модель валютного курса

В нашем исследовании предложена математическая модель прогнозирования валютного курса на основе факторов, верификация которых проведена выше. При этом, в процессе моделирования был сделан акцент на дополнительной проверке факторов валютного курса, характерных для модели экономики России, которой свойственна сырьевая направленность. Проведена верификация курса национальной валюты и цены на нефть марки Urals. На протяжении всего рассмотренного периода линейная корреляция цен на нефть и курса рубля по отношению к доллару США составила порядка 80\% (с обратным знаком). Вследствие чего, при построении модели фактор сырьевой направленности внешнеэкономической деятельности применительно для России был выбран в качестве одного из возможных для включения в математическое уравнение.

Анализ корреляции факторов на протяжении всего рассмотренного ретроспективного периода с 2000 по 2016 гг., а также необходимость учета параметра мультиколлинеарности (взаимообусловленности) влияющих факторов, позволил в конечном итоге определить следу- ющие факторы значимого влияния на величину валютного курса РФ:

- цена на нефть марки Urals;

- сальдо торгового баланса;

- счет операций с капиталом и финансовыми инструментами.

Средствами компьютерного моделирования в программном комплексе Statistica, получена конечная модель валютного курса РФ:

$\mathrm{Y}=76,67-0,149$ X1 - 0,00035 X2 + 0,000517 X3. где:

Y - среднеквартальный курс рубля по отношению к доллару США, руб. за 1 доллар США;

X1 - цена на нефть марки Urals, долларов США за 1 баррель;

Х2 - сальдо торгового баланса, млн. долларов США;

X3 - счет операций с капиталом и финансовыми инструментами, млн. долларов США.

Верификация модели позволила утверждать o eе практической применимости. Средняя ошибка отклонений эмпирических и фактических данных составила 9\% (рис. 8).

В итоге получена математическая модель, показывающая зависимость между курсом национальной валюты и величинами, характеризующими потоки на товарных рынках, рынках капиталов и рынках денег. Проверка модели при вводе в качестве ее параметров фактических значений факторных показателей позволила заключить о возможности ее практического применения для целей прогнозирования валютного курса страны. Исходной информацией модели выступают прогнозы цен на экспортируемые энергоносители, а также прогнозы внешнеэкономических показателей движения товарной, денежной массы и капитала.

\section{Заключение}

В глобальной финансово-экономической среде, где национальная экономика является ее сегментом (вход и выход в которую свободны), существует глубокая связь, с одной стороны, между валютным и денежным рынками, с другой - между рынками финансовых и реальных активов.

Рассмотрены пять факторов (переменных) влияния на курс национальной валюты: среднерыночные цены капитала; величина и характер сальдо трех балансов - текущего счета платежного баланса, торгового баланса, капитальных активов; наконец, размер и динамика ВВП. Эти факторы имеют не только рыночное происхож- 


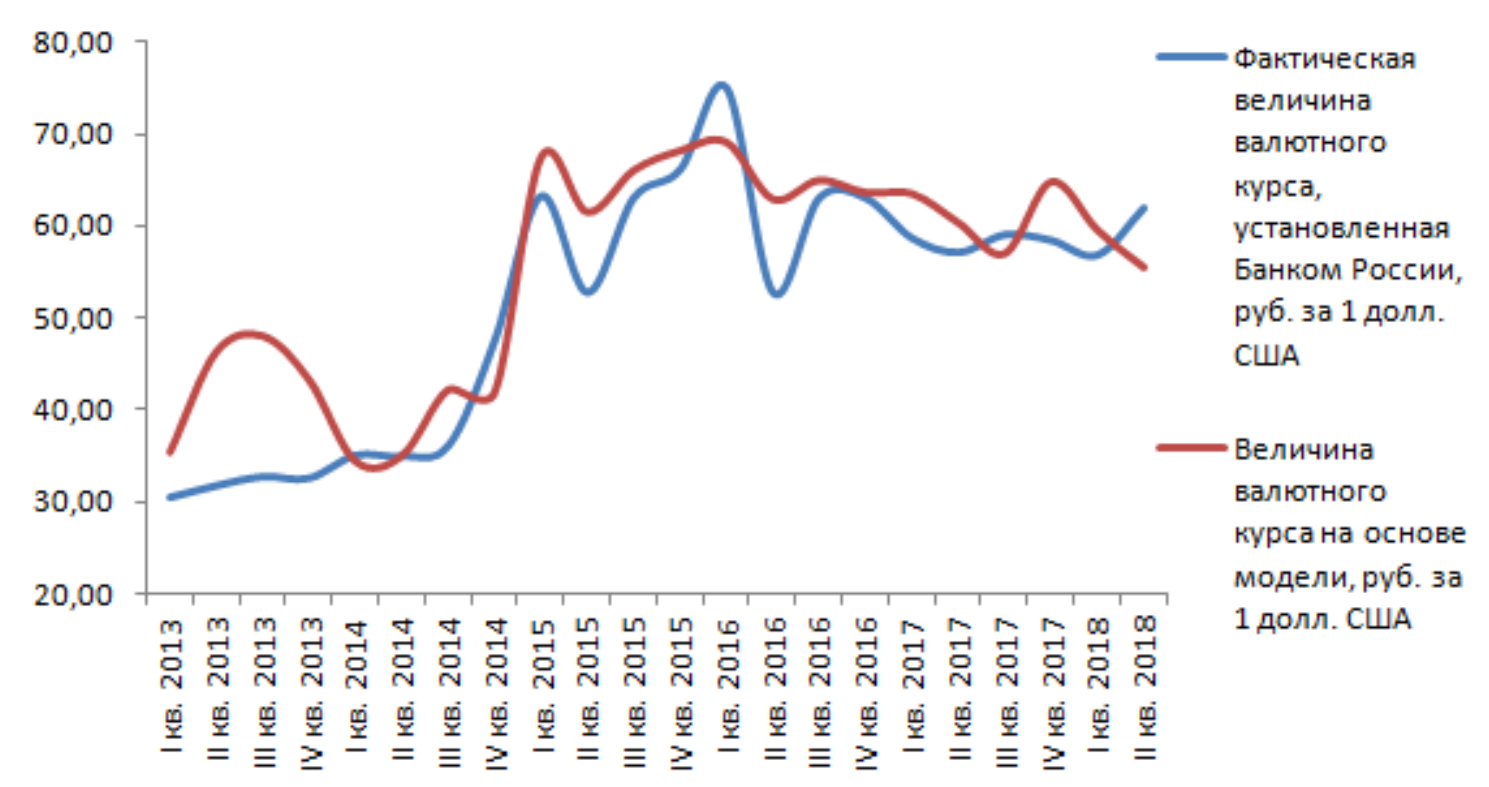

Puc. 8. Парные динамические ряды официального курса рубля РФ и расчетного значения валютного курса РФ, полученного на основе построенной модели Источник. Построено нами.

дение. Они являются в значительной степени результатом денежно-кредитного политики и регулирования. При этом количественная и качественная оценка переменных сделана на основе анализа статистических данных за длительные периоды ретроспективной динамики.

Проведённый анализ позволил выявить ряд закономерностей для национальной экономики, встроенной в глобальную финансово-экономическую среду.

Первое. Устойчивость национальных валют стран в современной мировой экономике определяется не только внутренними факторами и условиями для ведения бизнеса, превращения сбережений в инвестиции, но и в значительной мере факторами, ценовыми ориентирами, характеризующими деятельность стран на глобальных рынках реальных и финансовых активов.

Во-вторых, роль внешних факторов для формирования денежной массы, цены денег, размера для инвестиций, в конечном итоге, для потребления, благосостояния нации обусловлена масштабами национального сегмента в глобальной экономике.

В-третьих, устойчивость валютного курса рубля определяется, главным образом, присутствием российской экономики на экспортных рынках факторов производства. После валютных и нефтяных шоков 2014 г. и последующего кратковременного кризиса влияние фондирования с международных рынков денег, долговых обязательств и капитала стала ослабевать. На экспорт ориентированные экономики должны иметь альтернативные сценарии обеспечения стабильного курса валют и уметь их реализовывать на уровне макроэкономики и геоэкономики.

Четвертое. Построена математическая модель прогнозирования валютного курса рубля на основе данных о внешнеторговых потоках товаров, капиталов и денег в России, а также на прогнозах мировых цен на энергоносители.

Ограничения в исследовании и направления дальнейших исследований

В процессе проведенного исследования установлено, что одним из ограничителей при изучении динамики и прогнозирования валютных рынков и курсов выступает государственное регулирование национальной валюты. Естественное органическое изменение валютного курса происходит под воздействием спроса и предложения на валютном рынке, на которые, в свою очередь, влияют рыночные обстоятельства структурного и конъюнктурного характера.

Одновременно, правительственные меры регулирования, направленные на девальвацию или ревальвацию национальной валюты, удержание или плавное снижение/повышение посредством валютных интервенций, ограничивают рамки применения экономико-математических подходов к анализу и прогнозированию курсов национальных валют. По мере укрепления роли национальных экономик на 
глобальных рынках регулирующее начало государство объективно снижается. Тем самым, возможность применения инструментарных подходов к предсказанию поведения национальной валюты можно значительно расширить в будущем при преобладающей роли рыночных факторов на валютном рынке.

Валютная и денежно-кредитная политика, емкость и цена национального рынка денег зависят от масштабов и характера встроенности (интеграции) в глобальную финансово-эконо- мическую среду. Валютный курс, его волатильность, стабильность, эффективность национальной финансовой системы в целом зависят от комбинации внешних и внутренних факторов. Их научный анализ роли, места, корреляции предполагает всестороннее изучения входящих и выходящих финансовых потоков (как чистых, легальных, так и теневых), регистрируемых в платежном балансе и проходящих через валютообменные операции форекса.

\section{Библиографический список}

1. Борисов А.Н. Валютная интеграция как одна из основных тенденций развития мировой валютной системы на современном этапе / А.Н. Борисов // Экономические науки. 2012. № 92. С. 171-179.

2. Бюллетень банковской статистики Банка России [Электронный ресурс].- Режим доступа: https://www.cbr. ru. (Дата обращения 01.09.2018).

3. Для максимальной чистоты расчетов следует ориентироваться не просто на номинальный валютный курс, а учитывать реальный эффективный обменный курс (BIS real effective exchange rate (CPI-base 2010, monthly average), рассчитанный по курсам валют стран основных торгово-экономических партнеров и дефлированный на инфляцию. Более подробно таблицы BIS REER по 61 валютам мира с 1994 г. по н.в. см.: http://www.bis.org/statistics.

4. Росстат [Электронный ресурс]. - Режим доступа: https://www.gks.ru. (Дата обращения: 01.09.2018).

5. Хикс Дж. Р., Аллен Р. Дж.Д. Пересмотр теории ценности (A Reconsideration of the Theory of Value, 1934) // Вехи экономической мысли. Том 1. Теория потребления и спроса / под ред. В.М. Гальперина. Санкт-Петербург. 2000. С.117-141 (380 с.)

6. Хикс, Дж. Р. Капитал и рост (Capital and growth, 1965)// Вехи экономической мысли. Том 6. Международная экономика / под ред. А.П. Киреева. Москва. 2006. С.488-503. (720 с.)

7. Х Хикс, Джон Р. Стоимость и капитал (Value and Capital, 1939). Москва.1993. 488 с.

8. Хикс, Джон Р. Теория экономической истории (A Theory of Economic History, 1969). Москва. 2003. 224 c.

9. Киреев А.П. Международная экономика / А.П. Киреев. Т. 1. М.: Международные отношения, 2002. С.309.

10. Показатели мирового развития. Индикатор Экспорт / ВВП,\%, 2006-2017 [Электронный ресурс]. Режим доступа: http://data.trendeconomy.ru/dataviewer/wb/wbd/wdi?ref_area=RUS\&series=NE_EXP_GNFS_ZS. (Дата обращения 04.12.2018).

11. Внешняя торговля России в 2017 году [Электронный ресурс].- Режим доступа: http://russian-trade.com/ reports-and-reviews/2018-03/vneshnyaya-torgovlya-rossii-v-2017-godu/. (Дата обращения 04.12.2018).

12. BRICS Joint Statistical Publication: 2015; Brazil, Russia, India, China, South Africa / Rosstat. - Moscow: Statistics of Russia, 2015.- 235 p.

13. Current account balance, 2018, U.S. dollars.-https://www.imf.org/external/datamapper/BCA@WEO/ADVEC/ WEOWORLD/EURO (Дата обращения: 04.12.2018).

14. Filardo Andrew, Siklos Pierre. The cross-border credit channel and lending standards surveys //BIS Working Papers. N723. 09 May 2018.

15. Finance \& Development (F\&D) Issues, 2016-2018.- http://www.imf.org/external/pubs/ft/fandd/fda.htm (accessed 28.05.2018).

16. Güneş Kamber and Madhusudan Mohanty. Do interest rates play a major role in monetary policy transmission in China? // BIS Working Papers. No 714.06 Apr 2018.

17. Hansen Alvin Harvey. Monetary Theory and fiscal policy. N.Y. 1949.

18. Hayes Mark. The Economics of Keynes: A New Guide to the General Theory // Edward Elgar Publishing, 2008. 257 p.

19. Hicks John Richard. Mr Keynes and the Classics: A Suggested Interpretation, 1937.

20. Hicks John. IS-LM: An explanation// Journal of Post Keynesian Economics. 1980. № Vol III. No.2. C. 152.

21. Keynes John Maynard. The general theory of employment, interest \& money / John Maynard Keynes. Moscow. 2018. $342 \mathrm{p}$. 
22. Menna Lorenzo, Tobal Martin. Financial and price stability in emerging markets: the role of the interest rate //BIS Working Papers. No 717.04 May 2018.

23. Russia in figures. 2018: annual statistical report. Moscow: Rosstat, 2018. 522p.

24. Russian statistical yearbook. 2017.- Moscow: Rosstat, 2017. 686 c.

25. Russian and countries. 2016: statistical yearbook / Rosstat. Moscow, 2016. -379 p.

26. Sheehan Brendan. Understanding Keynes' General Theory. Palgrave Macmillan, 2009. 272 p.

27. The price, real and financial effects of exchange rates. - BIS Papers. No 96. 28 Mar 2018.

28. Topics of BIS Working Papers, 2017-2018. -https://www.bis.org/list/research/index.htm (accessed 26.05.2018)

29. http://www.baumanrarebooks.com/rare-books/keynes-john/81560.aspx.

30. http://ecsocman.hse.ru/data/367/700/1219/009Hiks.pdf. 